\title{
REASSESSMENT OF INTERNATIONAL APPLICATION OF ANTITRUST LAWS: BLOCKING STATUTES, BALANCING TESTS, AND TREBLE DAMAGES
}

\section{INTRODUCTION}

In the landmark decision of United States $v$. Aluminum Company of America, ${ }^{1}$ the Second Circuit ${ }^{2}$ held that U.S. courts have subject matter jurisdiction over antitrust activity committed abroad if it affected, and was intended to affect, commerce in the United States. ${ }^{3}$ That decision has become the cornerstone of enforcement of U.S. antitrust laws abroad.

Since the Alcoa decision in 1945, extraterritorial enforcement of U.S. antitrust laws has caused increasingly serious economic and political problems for the United States. ${ }^{4}$ The extraterritorial application of our antitrust laws is problematic for several reasons. Only the United States, the European Economic Community, and the Federal Republic of Germany vigorously enforce their competition laws against conduct outside their borders. ${ }^{5}$ Moreover, only the United States allows recovery of treble damages in private legal actions seeking to apply antitrust laws to persons acting outside its borders. ${ }^{6}$

The conflicting policies among nations regarding their antitrust laws have led to many international conflicts over the years. ${ }^{7}$ These conflicts injure U.S. foreign relations and hinder the promotion of U.S. foreign policy. In fact, these conflicts have led to specific reprisals against U.S. government policy, the most serious of which is the blocking legislation initiated by several

Copyright $\odot 1988$ by Law and Contemporary Problems

1. 148 F.2d 416 (2d Cir. 1945).

2. The Second Circuit heard the case on certification from the Supreme Court because the latter lacked a quorum of Justices as the result of disqualifications from the case.

3. 148 F.2d at 443-44. It appears that the Supreme Court recently reaffirmed this test in Matsushita Elec. Industries v. Zenith Radio Corp., 106 S. Ct. 1348, 1354 (1986); see also Restatement on Foreign Relations Law § 415(2) (Tent. Draft No. 6 1955).

4. Hearings on S. 397 before the Senate Comm. on the Judiciary, 99th Cong., 1st Sess. 57 (1985) [hereinafter S. 397 Hearings] (statement of James F. Campbell and David Westin, Attorneys, Wilmer, Cutler and Pickering, Washington, D.C.). S. 397 was reintroduced this term as S. 572.

5. S. 397 Hearings, supra note 4 , at 58.

6. Id. at 8 .

7. For a discussion of the specific conflicts caused by extraterritorial enforcement of U.S. antitrust laws, see S. 397 Hearings, supra note 4, at 62-68. 
foreign countries. ${ }^{8}$ These blocking statutes evidence foreign disdain for American antitrust laws, and are designed to create a disincentive for the extraterritorial reach of U.S. antitrust laws. There are two kinds of blocking statutes: First, there are discovery blocking statutes aimed at preventing compliance with foreign state requests or orders for documents or information. Second, there are judgment blocking provisions that declare unenforceable in whole or in part the decisions or orders of a foreign court purporting to affect foreign nationals. ${ }^{9}$

This note analyzes the practical effects of the blocking statutes on antitrust litigation and the proposed solutions to the extraterritoriality conflict. Section II of this note summarizes the provisions of several blocking statutes. Section III examines two recent antitrust cases in which foreign countries invoked blocking statutes to impede the litigation. It also summarizes the views of several renowned litigators who have encountered blocking statutes in their practices. Section IV analyzes current legislative and governmental initiatives that propose to revise U.S. antitrust laws in order to accommodate foreign concerns. Section $\mathrm{V}$ posits that the proposed revisions to U.S. antitrust laws are not likely to lead to parallel movements in other countries to repeal their blocking legislation. Although these efforts may prompt some modest modifications in blocking laws and foreign relations, the effects of the legislation are unlikely to be significant enough to justify changes in U.S. antitrust policy. Therefore, the note concludes that domestic considerations alone should motivate changes in U.S. antitrust law.

\section{II}

\section{The Blocking Legislation}

A. Perceived Abuses by the United States that Prompted Blocking Legislation

England, France, Canada, and Australia are among the countries that have passed blocking legislation at least in part in response to perceived abuses by the United States in the extraterritorial application of its antitrust laws. These four countries have passed blocking legislation to protect their domestic industries from actions by the United States Government and private litigants in the Uranium Antitrust Litigation.

The Uranium Antitrust Litigation began in the 1970's when the Justice Department investigated the uranium production industry. ${ }^{10} \mathrm{~A}$ number of private suits were also filed. In one private action, Westinghouse Electric Corporation alleged that uranium producers outside the United States had formed a cartel that raised the price of uranium so much that it rendered

8. For a discussion of other consequences stemming from conflicting assertions of extraterritorial jurisdiction, see Small, Managing Extraterritonial Junisdiction Problems: The United States Government Approach, LAW \& ConTEMP. PROBS., Summer 1987, at 283, 284-87.

9. See Note, Shortening the Long Arm of American Antitrust Jurisdiction: Extraterritoriality and the Foreign Blocking Statutes, 28 Loy. L. REv. 213,214 n.6 (1982).

10. See United States v. Gulf Oil Corp., Crim. No. 78-123 (E.D. Pa., filed May 9, 1978). 
performance of its uranium contracts commercially impracticable. ${ }^{11}$ In the discovery phase of the litigation, Westinghouse attempted to obtain documents and testimony from foreign producers. These requests prompted retaliatory responses from foreign nations believing that the Uranium litigation represented an attempt by the United States to enforce unilaterally its economic and commercial policies abroad.

Westinghouse attempted to obtain documents and testimony from officials of Rio Tinto Zinc, Ltd., a British uranium producer named as a defendant. In order to obtain this information, Westinghouse presented letters rogatory ${ }^{12}$ to the British courts. ${ }^{13}$ When the case reached the House of Lords, ${ }^{14}$ the British government intervened, positing that British national interests required denial of the discovery requests. ${ }^{15}$ In response to the Uranium litigation, Canada passed legislation limiting the extraterritorial reach of

11. Westinghouse alleged that the cartel fixed prices, allocated markets, and boycotted certain competitors, including Westinghouse.

12. Letters rogatory are legal papers by which a court in one country requests a court in another country to use its processes to obtain information within its jurisdiction for transmittal to the court of the requesting country.

13. Westinghouse used the procedures established by the Hague Convention on the Taking of Evidence Abroad in Civil or Commercial Matters, opened for signature Mar. 18, 1980, 23 U.S.T. 2555, T.I.A.S. No. 7444. At that time, an English statute designed to follow the convention was in place. Evidence (Proceedings in Other Jurisdictions) Act, 1975, Ch. 34. See D. Hacking, The Increasing Extraterritorial Impact of U.S. Laws: A Cause for Concern Amongst Friends of America, Address to the Los Angeles County Bar Association (June 27, 1978), reprinted in Perspectives on The Extraterritorial Application of U.S. Antitrust and Other Laws 155, 166 (J. Griffin ed. 1979).

14. Two lower British courts granted part of the discovery request. See D. Hacking, supra note 13 , at 166

15. [1978] I All E.R. 434 (H.L. 1977). One commentator believes that this event was most responsible for turning British official opinion against American antitrust enforcement. See D. Hacking, supra note 13, at 167-68.

Other U.S. actions also contributed to the tension between the United States and Great Britain. The Justice Department's criminal actions against the major North Atlantic shipping companies in 1979 were one source of tension. In these actions, the Justice Department prosecuted several foreign domestic shipping companies for price fixing outside the regulatory framework established to monitor shipping conferences. United States v. Atlantic Container Line, Crim. No. 79-00271 (D.D.C. filed June 1, 1979); United States v. Bates, Crim. No. 79-00272 (D.D.C., filed June 1, 1979).

The Justice Department charged that the individuals deliberately withheld information about their dealings from the United States Federal Maritime Commission in order to conceal the violations. After pleas of nolo contendere by all defendants in 1979 and imposition of $\$ 6.1$ million fines against them, the British Trade Secretary indicated that this unilateral action by the United States would lead the British to reconsider their cooperation with the United States on antitrust matters.

"British Threaten Retaliation Over Shipping Antitrust Judgments," [July-Dec.] ANTITRUst \& Trade Reg. RPT. (BNA No. 922, at A-30 (July 12, 1979). The subsequent filing of more than thirty private treble damage complaints further exacerbated the problem. See In re Ocean Shipping Antitrust Litig., 1982-1 Trade Case (CCH) ๆ 64,585 (S.D.N.Y. 1982) (approving \$51.4 million settlement of the claims).

Although Great Britain's blocking statute is directed against all foreign authorities, the debates on the legislation confirm the belief that the British were reacting to encroachments upon British jurisdiction by the United States. During the debates in the House of Commons, John Nott, the British Secretary of State for Trade, stated:

In theory, this [attempts by other countries to enforce their commercial policy unilaterally in the United Kingdom] is a general problem .... In effect, however, the practices to which successive United Kingdom governments have taken exception have arisen in the case of the United States of America.

973 Parl. Deb., H.C. (5th Ser.) 1533 (1979). During the debates in the House of Lords, another British official noted: 
American antitrust law. As an amendment to its own antitrust law, Canada first passed legislation empowering the Canadian Restrictive Trade Practice Commission to bar implementation of foreign legal judgments having adverse effects on competition in Canada. ${ }^{16}$ In addition to these provisions, Canada passed the Uranium Information Security Regulations in 1976. ${ }^{17}$ These regulations were specifically aimed at preventing the disclosure of documents located in Canada to the U.S. grand jury and litigants in the private Uranium litigation.

In a related action, a U.S. court did not apply the act of state doctrine ${ }^{18}$ to a French producer who failed to appear and contest the court's jurisdiction. The French government viewed this action as a rejection of comity principles, because it allowed the courts of one nation to inquire into the conduct of those acting under the instruction of another sovereignty. ${ }^{19}$ As a result, France enacted a blocking statute. ${ }^{20}$

[T]he United States has over the last three decades shown a tendency increasingly to try to mould the international economic and trading world in its own image. This is an attitude not only of the United States legislature, but it is shared by its courts and its enforcement agencies, all of whom have contributed to the matters to which we take objection.

40 Parl. Deb., H.L. (5th Ser.) 555 (1980).

16. Act of Dec. 15, 1975, Ch. 76, § 31.5, 1975 CAN. STat. 1535 (amending Combines Investigation Act, Can. Rev. Stat. ch. C-23 (1970)).

17. Uranium Information Security Regulations, Can. Cons. Regs. ch. 366 (1978), as amended by 115 Can. Gaz. Part II 3513 (Dec. 12, 1981), issued pursuant to the Atomic Energy Control Act, Can. Rev. Stat, ch. A-19 (1970).

Canada explained the rationale for these regulations as follows:

Canada considered it contrary to her sovereign prerogatives for foreign tribunals to question the propriety or legality of the actions of Canadian uranium producers that were taken outside the United States and were required by Canadian law or taken in implementation of Canadian government policy.... The Canadian government promulgated the Regulations to serve a vital national interest, particularly the preservation of Canada's past and future sovereign authority, to secure compliance with its own laws and policies respecting a vital Canadian natural resource in the face of assertions of jurisdiction by non-Canadian tribunals.

Amicus curiae filing of the Canadian government, quoted in Gulf Oil Corp. v. Gulf Canada Ltd., 19801 Trade Case (CCH) I 63,285, at 78,453 (Can. 1980).

18. The act of state doctrine requires a court to abstain from asserting its jurisdiction where to do so would question the validity of the actions of a foreign state or sovereign. See generally Banco National de Cuba v. Sabbatino, 376 U.S. 398 (1964). In an action by Westinghouse against a French uranium producer, the French government took the position that the firm's involvement in the alleged uranium cartel was under instruction from the appropriate French authorities. The French government believed that such instruction warranted application of the act of state doctrine. See Memorandum of Government to France to the United States Department of State (Oct. 27, 1978) filed in United States District Court for the Northern District of Illinois, June 8, 1979, quoted in Note, supra note 9, at 262.

19. Memo, supra note 18, quoted in Note, supra note 9 , at 263 n.290.

20. In re Uranium Antitrust Litig., 473 F. Supp. 382 (N.D. Ill. 1979), modified 617 F.2d 1248 (7th Cir. 1980).

Several other U.S. actions also contributed to passage of the French blocking legislation. First, in the mid-1970's, the United States Justice Department requested information regarding the activities of a French airline carrier. See Toms, The French Response to the Extraterritorial Application of United States Antitrust Laws, 15 INT'L LAW. 585, 588 (1981). Second, Congress passed the Airline Deregulation Act, which increased the antitrust exposure of foreign air carriers by requiring them to conform to American concepts of fair competition. Airline Deregulation Act, § 102(a)(7), 92 Stat. 1705, 1706-07 (1978) (current versions at 49 U.S.C. $\$ 1302$ (1982 \& Supp. 1985)); see also Toms, supra, at 588. Finally, the Federal Trade Commission's attempt to serve document requests on a French company as part of its investigation of the fiberglass insulation industry also contributed to the problem. FTC 
Finally, the Uranium Antitrust Litigation triggered passage of two pieces of blocking legislation in Australia, one barring discovery21 and the other barring the enforcement of foreign judgments. ${ }^{22}$ The Australian government took a strong stand with regard to the U.S. investigation of the uranium producers because

of the severe effects which a damages judgment may have on the Australian economy, in such fields as the financing of resources projects, attraction of foreign investment, trade in uranium and other commodities, and the financial viability of the . . companies concerned, all of which play a major role in the production and export of Australia's natural resources. ${ }^{23}$

Australia enacted its restrictive discovery statute shortly after Westinghouse presented letters rogatory to the Australian judiciary in an attempt to obtain information about Australian participation in the cartel. ${ }^{24}$ In spite of the restrictive discovery statute, the United States continued its investigation and attempted to secure more documents located in Australia. The subsequent refusal of the Australian producers to appear in court led Australia to fear that U.S. courts might enter default judgments against Australian companies. To prevent enforcement of these judgments, Australia passed legislation empowering the Attorney General to issue orders barring the enforcement of foreign antitrust judgments in Australian courts. ${ }^{25}$

\section{B. The Provisions}

Some blocking statutes contain provisions that both block the discovery of documents located in their countries and bar the enforcement of foreign judgments. Others concentrate on only one goal. France's blocking statute, for example, is aimed solely at restricting the discovery of information on economic, commercial, and technical matters. ${ }^{26}$ It prohibits French nationals from producing documents or information of a commercial nature potentially harmful to the security interests or essential economic interests of France. ${ }^{27}$ The law also prohibits anyone inside or outside of France from requesting

v. Compagnie De Saint-Gobain-Pont-A-Mousson, 636 F.2d 1300 (D.C. Cir. 1980) (holding invalid the FTC's attempt to serve investigatory subpoenas upon a French corporation by registered mail).

21. Foreign Proceeding (Prohibition of Certain Evidence) Act, No. 121 of 1976, as amended by Foreign Proceeding (Prohibition of Certain Evidence) Amendment Act, No. 202 of 1976 (Austl.).

22. Foreign Antitrust Judgments (Restriction of Enforcement) Act, No. 13 of 1979 (Austl.).

23. Diplomatic Note No. $390 / 79$ from the Australian Embassy to the United States Department of State, Oct. 19, 1979, at 3, reprinted in Note, supra note 9, at $244 \mathrm{n} .177$.

24. In re Westinghouse Electric Corp. Uranium Contract Litig., No. G.D. 75-23978 (N.S.W. S. Ct. 1976).

25. Foreign Antitrust Judgments (Restriction of Enforcement) Act, No. 13 of 1979 (Austl.), $\S 3(2)(c)$.

26. Law Concerning the Communication of Economic, Commercial, Industrial, Financial or Technical Documents or Information, Law No. 80-538, 1980 J.O. 1799 (July 16, 1980) [hereinafter cited as French Blocking Law]. A translation of relevant portions of this statute appears in FTC v. Compagnie De Saint-Gobain-Pont-A-Mousson, 636 F.2d 1300, 1326 nn.146-47 (D.C. Cir. 1980). This law was an amendment to an already existing blocking statute that prohibited the release of documents and information relating to the French shipping industry. Law No. 68-678 of July 26, 1968 J.O. 7267. The French passed the latter act in response to an investigation of several French shipping companies.

27. French Blocking Law, supra note 26, at art. I. 
documents of a commercial nature from a French enterprise. ${ }^{28}$ Perhaps the most interesting feature of the French law is that it is self-executing. Unlike other foreign blocking statutes, the prohibitions contained in the Act do not require administrative implementation. ${ }^{29}$

Great Britain's blocking statute, the Protection of Trading Interests Act, ${ }^{30}$ is an example of the type of statute that both restricts discovery provisions and bars enforcement of foreign judgments. The Act authorizes the British Secretary for Trade to block foreign discovery requests when the material sought is outside the territorial jurisdiction of the ordering country ${ }^{31}$ and to bar enforcement of foreign judgments for multiple damages against British defendants. ${ }^{32}$ It gives the Secretary of State authority over noncompliance with any foreign requirement or prohibition where appropriate for avoiding damage to the trading interests of the United Kingdom. ${ }^{33}$ The Act also has a clawback provision that allows British companies to recover in British courts the noncompensatory portion of any foreign multiple damage judgment entered against them where the judgment was not based exclusively on conduct occurring within the territory of the country imposing the judgment. ${ }^{34}$

Both Canada and Australia have recently passed far-reaching blocking statutes. The Canadian Parliament passed the Foreign Extraterritorial Measures Act in $1984 . .^{35}$ The Act contains a clawback provision similar to that contained in the British Protection of Trading Interests Act ${ }^{36}$ and permits the Canadian government to order Canadian companies not to comply with foreign regulations. ${ }^{37}$ It also empowers the Attorney General to issue orders preventing enforcement in Canada of foreign antitrust judgments ${ }^{38}$ and to bar or restrict the production or disclosure of any records in the possession or control of a Canadian resident to a foreign court asserting extraterritorial jurisdiction. ${ }^{39}$

28. Id. art. I.

29. Id. art. I; see also Toms, supra note 20 , at 592.

30. The Protection of Trading Interests Act, 1980, ch. 11, reprinted in [Jan.-June] ANTrTrust \& Trade Reg. ReP. (BNA) No. 959, at F-1, 2 (Apr. 10, 1980).

31. Id. $\$ 2$.

32. Id. $\$ 5$.

33. Id. $\$ 1$.

34. Id. $\$ 6$.

35. Foreign Extraterritorial Measures Act, Ch. 49, 1984 Can. Stat. 1867. An earlier bill, the Foreign Proceedings and Judgments Act, Bill C-41, 32d Parl., 1st Sess. (Can. 1980), was introduced in 1980 but died when the thirty-first session of the Canadian Parliament ended. It is significant that the bill was reintroduced in the thirty-second session of Parliament. One Canadian representative noted that his government viewed the extraterritoriality issue as an ongoing concern, "not as a kneejerk reaction to a special dispute." "Canadian Government Sponsors Bill to Address Extraterritoriality Issue," 46 Antitrust \& Trade Reg. Rep. (BNA) No. 1168, at 1106 (June 7, 1984).

36. Foreign Extraterritorial Measures Act, Ch. 49, s 9, 1984 CAN. Stat. 1867.

37. Id. \& 5, 1984 Can. Stat. at 1866-67.

38. Id. $\$ 8,1984$ CAN. Stat. at 1868.

39. Id. § 3, 1984 Can. Stat. at 1864-65. This provision even applies to documents of a Canadian national that are located in the United States. 
Australia also passed its new blocking legislation in $1984.4^{40}$ One section of the Act goes even further than the clawback provision contained in the British Protection of Trading Interests Act. It authorizes recovery by an Australian national of the full amount, not just the noncompensatory portion, of any foreign treble damages judgment imposed in a foreign country for violating that nation's antitrust laws. ${ }^{41}$

Both Canada and Australia passed blocking legislation despite the existence of antitrust cooperation agreements with the United States regarding U.S. antitrust enforcement. Canada's agreement ${ }^{42}$ requires the United States to notify and consult ${ }^{43}$ Canada whenever U.S. antitrust enforcement efforts affect Canadian interests. ${ }^{44}$ The United States is also to use voluntary methods of obtaining documents in Canada before resorting to compulsory process. ${ }^{45}$ Furthermore, the United States Government must participate in private antitrust suits relating to conduct that has become the subject of notification and consultation if Canada so requests. ${ }^{46}$

The mutual assistance agreement with Australia ${ }^{47}$ is similar to the Canadian agreement. One significant difference, however, is that it requires Australia to exercise forbearance in the use of its discovery blocking legislation. It provides that the mere issuance of legal process in one country in order to obtain documents in the other does not in itself contravene the national interests of the other country or give sufficient cause to invoke official measures preventing compliance. ${ }^{48}$

There are several explanations for the passage of these blocking statutes despite the existence of the antitrust cooperation agreements. First, nothing in the agreements prevents the United States from using compulsory discovery processes should circumstances so warrant. In addition, no provisions bar enforcement of foreign court orders or judgments. Finally, the agreements cannot resolve the problems stemming from private antitrust litigation because the government cannot control private treble damages actions. ${ }^{49}$ Thus, until there is a solution to the problem of private treble

40. Foreign Proceedings (Excess of Jurisdiction) Act No. 3 of 1984 (Austl.).

41. Id. § 10 .

42. Memorandum of Understanding between the Government of the United States of America and Canada as to Notification, Consultation and Cooperation with Respect to the Application of National Antitrust Laws, reprinted in 46 Antitrust \& TRADE REG. ReP. (BNA) No. 1156, at 560 (March $15,1984)$.

43. Id. $\$ 2,47$ Antitrust \& Trade Reg. Rep. at 560.

44. Id. $\$ 4,46$ Antitrust \& TRADE Reg. ReP. at 560-61.

45. Id. $\$ 8,46$ Antitrust \& TRADE Rf.c. Rep. at 561. This provision contains a caveat: Either party to the agreement may resort to compulsory process if the circumstances so warrant.

46. Id. $\S \S 11(1), 46$ Antitrust \& Trade Reg. ReP. at 562.

47. Agreement Between the Government of the United States of America and the Government of Australia Relating to Cooperation on Antitrust Matters, June 29, 1982, reprinted in 43 ANTITRUst \& Trade Reg. Rep. (BNA) No. 1071, at 36 (July 1, 1982).

48. Id. art. 5.

49. An Australian attorney, speaking at an International Bar Association meeting on antitrust law, commented that the Australian blocking legislation is designed to force private plaintiffs in the United States to think twice before drawing an Australian national into treble damages litigation. See 
damages actions, Canada and Australia are likely to apply their blocking legislation to these types of cases.

Without a solution to the problems created by private suits, it does not appear that the United States and Great Britain will be able to resolve their differences either. The United States does not have the partial solution of an antitrust cooperation agreement with England. Furthermore, the British recently revealed that they are serious about enforcing the Protection of Trading Interests Act by invoking its provisions in an antitrust action. ${ }^{50}$ The British take the position that change will be possible only if the United States accepts the increased interdependence of the western economies and adjusts its economic policies to reflect this change. ${ }^{51}$

Finally, without a solution to the treble damages problem between the United States and Canada, extraterritorial conflicts will probably remain. France and the United States have not reached a cooperation agreement, and one French commentator believes that the French law will be enforced vigorously with respect to actions brought under U.S. antitrust laws against French parties. ${ }^{52}$

\section{III}

\section{The Impact of Foreign Blocking Legislation on ANTitrust} JURISPRUDENCE aNd Litigation STRATEgy

To date, blocking legislation has only affected two antitrust cases: the Uranium $^{53}$ litigation and the Laker Airways ${ }^{54}$ litigation. This section analyzes the impact of blocking legislation in these suits. Because blocking statutes also affect litigation in the planning stages, this section also assesses the impact of these statutes on litigation strategy.

\section{A. Case Law}

1. The Uranium Antitrust Litigation. Westinghouse alleged in a private action that a cartel existed among both its domestic and foreign competitors to restrain uranium trade. ${ }^{55}$ Foreign governments invoked blocking legislation to protest requests by Westinghouse for documents belonging to foreign defendants. Invocation of the blocking statutes by foreign nations demonstrated foreign hostility toward the exercise of jurisdiction by a U.S. district court.

\footnotetext{
"IBA Committee Explores Market Reliance, Blocking, Clawback, Corporate Compliance," 49 Antitrust \& Trade Reg. Rep. (BNA) No. 1237, at 717 (Oct. 24, 1985).

50. The British invoked this statute in Laker Airways v. Sabena, Belgian World Airlines, 731 F.2d 909 (D.C. Cir. 1984). Section III of this note, infra, discusses this case at length.

51. 973 Parl. Deb. H.C. (5th Ser.) 1538 (1979).

52. Toms, supra note 20 , at 606 .

53. In re Uranium Antitrust Litig., 473 F. Supp. 382 (N.D. Ill. 1979), modified 617 F.2d 1248 (7th Cir. 1980).

54. 559 F. Supp. 1124 (D.D.C. 1983), aff'd sub nom. Laker Airways v. Sabena, Belgian World Airlines, 731 F.2d 909 (D.C. Cir. 1980).

55. For a summary of the Westinghouse allegations, see supra note 10.
} 
The jurisdictional issue arose when the twelve foreign producers named in the Westinghouse complaint failed to respond to judicial summons. Judge Marshall entered a default judgment against them. ${ }^{56}$ On an interlocutory appeal to the Seventh Circuit, several foreign governments appearing as amici curiae argued unsuccessfully that the district court should not have exercised jurisdiction over the defendants because of comity considerations. ${ }^{57}$

As support for this argument, the foreign governments relied on Timberlane Lumber Co. $v$. Bank of America ${ }^{58}$ and Mannington Mills, Inc. $v$. Congoleum Corp. ${ }^{59}$ These decisions, from the Third and Ninth Circuits respectively, employed balancing tests in determining whether to exercise

56. In $r e$ Uranium Antitrust Litig., 473 F. Supp. 382 (N.D. Ill. 1979).

57. In re Uranium Antitrust Litig., 617 F.2d 1248, 1253 (7th Cir. 1980).

58. Timberlane Lumber Co. v. Bank of America, 549 F.2d 597 (9th Cir. 1976). In that case, Timberlane, a lumber company, attempted to enter the Honduran timber export market through the acquisition of a failing company. Timberlane alleged that the Bank of America and other creditors had forced the previous owner's operation into bankruptcy, and then tried to drive Timberlane out of the country by refusing to settle the debts that Timberlane had assumed. The district court dismissed the complaint on act of state and jurisdictional grounds.

The Ninth Circuit reversed on both grounds. On the jurisdictional issue, the court could have reversed the district court based on the effects test of Alcoa. See $1 \mathrm{~J}$. Atwoon \& K. Brewster, supra note 9 , at 160 . But Judge Choy instead developed a new jurisdictional test that placed some limitations on the Alcoa approach. He wrote:

The effects test by itself is incomplete because it fails to consider other nations' interest. Nor does it expressly take into account the full nature of the relationship between the actors and this country. ...

American courts have, in fact, often displayed a regard for comity and the prerogatives of other nations and considered their interests as well as other parts of the factual circumstances, even when professing to apply an effects test.

549 F.2d at $611-12$ (footnotes omitted).

Judge Choy therefore suggested a three part approach to jurisdictional issues. Id. at 613 . The first step requires the plaintiff to show "some effect-actual or intended-on American foreign commerce. . ." Id. Under the second step, the court must determine whether the restraint was of the type and magnitude to be cognizable as a violation of the U.S. antitrust laws. The third step requires the court to balance American interests against foreign interests in order to determine whether the American interests are strong enough in relative terms to justify exercising jurisdiction.

Having developed this test, Judge Choy remanded the case to the district court for a factual determination of whether the exercise of jurisdiction was proper. On remand, the lower court received extensive evidence and concluded that the dismissal of the action for lack of subject matter jurisdiction was appropriate. Timberlane Lumber Co. v. Bank of America, 574 F. Supp. 1453, 1460 (N.D. Cal. 1983). On appeal, the Ninth Circuit affirmed the district court's dismissal for lack of subject matter jurisdiction. The court found that Timberlane had satisfied the first two steps of the three part approach, but concluded that the foreign interests at stake outweighed American interests in the transaction. The court concluded that extraterritorial application of U.S. antitrust law to this transaction would create "a political conflict with the Honduran government"s effort to foster a particular type of business climate." Timberlane Lumber Co. v. Bank of America, 749 F.2d 1378. 1384 (9th Cir. 1976), cert. denied, 105 S. Ct. 3514 (1985). The court also concluded that the effect in Honduras outweighed the effect on the foreign commerce of the United States because Honduran lumber accounted for, at most, three to four percent of total U.S. imports. Id. at 1385.

59. Mannington Mills, Inc. v. Congoleum Corp., 595 F.2d 1287 (3d Cir. 1979). In that case, Mannington Mills alleged that the patent licensing practices of Congoleum for its embossed vinyl flooring violated the antitrust laws. Congoleum and Mannington had entered into an agreement in which Congoleum permitted Mannington to manufacture its licensed products in the United States for export sale to twenty foreign countries. When Mannington attempted to sell the products in countries not designated in the agreement, Congoleum sought to revoke Mannington's foreign licenses. Id. at 1290 .

The Third Circuit found that it was proper to exercise jurisdiction, but stressed that the court must consider competing foreign interests in making its jurisdictional determinations: 
jurisdiction over antitrust cases involving foreign defendants. Both tests, although slightly different, ${ }^{60}$ require the courts to consider whether the interests of the United States in exercising jurisdiction are sufficiently strong, "vis-a-vis those of other nations, to justify an assertion of extraterritorial authority."61

The Seventh Circuit in the Uranium case rejected the argument against the exercise of extraterritorial jurisdiction, holding that the district court had jurisdiction under the "effects" doctrine articulated in the Alcoa decision. ${ }^{62}$ The court stated that it did not find the Timberlane and Mannington Mills decisions controlling. ${ }^{63}$ It also held that the defaulters' refusal to appear would place the district court in an impossible position if it tried to apply this jurisdictional rule of reason without their participation in discovery. ${ }^{64}$

Meanwhile, Westinghouse's efforts to secure foreign documents under the control of affiliates of appearing defendants led to a discovery motion in the district court. ${ }^{65}$ Several of the defendants invoked foreign nondisclosure laws as a bar to production. Judge Marshall refused to employ a balancing test that would consider foreign law before entering an order compelling discovery. Relying on the Supreme Court's landmark decision in Societe Internationale v.

In a purely domestic situation, the right to a remedy would be clear. When foreign nations are involved, however, it is unwise to ignore the fact that foreign policy, reciprocity, comity, and limitations of judicial power are considerations that should have a bearing on the decision to exercise or decline jurisdiction.

Id. at 1296.

60. The Timberlane court considered the following factors:

[T] he degree of conflict with foreign law or policy, the nationality or allegiance of the parties and the locations or principal places of business of corporations, the extent to which enforcement by either state can be expected to achieve compliance, the relative significance of effects on the United States as compared with those elsewhere, the extent to which there is explicit purpose to harm or affect American commerce, the foreseeability of such effect, and the relative importance to the violations charged of conduct within the United States as compared with conduct abroad. Timberlane, 549 F.2d at 614 .

The Mannington Mills court indicated that the balancing process should entail consideration of these factors:

1. Degree of conflict with foreign law or policy;

2. Nationality of the parties;

3. Relative importance of the alleged violation and conduct here compared to that abroad;

4. Availability of a remedy abroad and the pendency of litigation there;

5. Existence of intent to harm or affect American commerce and its foreseeability;

6. Possible effect upon foreign relations if the court exercises jurisdiction and grants relief;

7. If relief is granted, whether a party will be placed in the position of being forced to perform an act illegal in either country or be under conflicting requirements by both countries;

8. Whether the court can make its order effective;

9. Whether an order for relief would be acceptable in this country if made by the foreign nation under similar circumstances;

10. Whether a treaty with the affected nations has addressed the issue.

Mannington Mills, 595 F.2d at 1297-98.

61. Timberlane, 549 F.2d at 613.

62. In re Uranium Antitrust Litig., 617 F.2d 1248, 1254 (7th Cir. 1980).

63. Id. at 1255 .

64. Id. at 1256 .

65. In re Uranium Antitrust Litig., 480 F. Supp. 1138 (N.D. III. 1979) 
Rogers, ${ }^{60}$ Judge Marshall held that only three factors were relevant to the court's determination whether to order production:

(1) The importance of the policies underlying the United States statute that forms the basis for the plaintiff's claims;

(2) the importance of the requested documents in illuminating key elements of the claim; and

(3) the degree of flexibility in the foreign nation's applications of nondisclosure laws. ${ }^{67}$

He explicitly rejected the defendants' argument that the court should adopt a broader balancing of interests approach where a conflict arises with a foreign nondisclosure law. ${ }^{68}$ He further reasoned that the "judiciary has little expertise, or perhaps even authority to evaluate the economic and social policies of a foreign country." 69 Finally, Judge Marshall noted that a balancing test is inherently unworkable where the competing interests at stake are totally at odds with each other. He stated:

The competing interests here display an irreconcilable conflict on precisely the same plane of national policy. Westinghouse seeks to enforce this nation's antitrust laws ... and to that end has sought documents located in foreign countries where [the defendants] . . . conduct their business. In specific response to this and other related litigation in the American courts, three foreign governments have enacted nondisclosure legislation which is aimed at nullifying the impact of American antitrust

66. 357 U.S. 197 (1958). This decision set standards for whether sanctions should be imposed for noncompliance with a domestic discovery order despite the interdictions of a foreign nondisclosure law. In Societe, a Swiss company brought suit under the Trading with the Enemy Act to recover assets that the United States Government had seized during World War II as enemy-owned property. The district court first ordered production and then dismissed the suit because of plaintiff's failure to produce certain documents, release of which was prohibited by Swiss law. The Supreme Court reversed dismissal of the suit, suggesting that a crucial factor in deciding whether to impose sanctions for noncompliance with a discovery order was whether there was a good faith effort to avoid the limitations of the foreign nondisclosure law. Id. at 208.

However, the Court upheld the validity of the production order. The Court implied that it would issue a production order if to do so would effectuate strong congressional policies. Moreover, it did not balance the disclosure policies of the American statute against the secrecy policies of Swiss law, indicating that the courts need only inquire into the strength of American interests. See id. at 205. The court also considered whether the documents were crucial to the resolution of a key issue in the litigation. Finally, the court considered the chances for flexibility in a country's application of its nondisclosure laws; the greater the flexibility, the greater the likelihood that a production order would issue. See id. at 205 .

67. In re Uranium Antitrust Litig., 480 F. Supp. 1138, 1148 (N.D. Ill. 1979).

68. The defendants argued that the court should adopt the analysis set forth in section 40 (a) of the Restatement (Second) of Foreign Relations Law of the United States. Section 40(a) requires that each state moderate the exercise of its enforcement jurisdiction in light of: (a) The vital national interests of each of the states; (b) the extent and nature of the hardship that inconsistent enforcement actions would impose upon a person; (c) the extent to which the required conduct is to take place in the territory of the other state; (d) the nationality of the person; and (e) the extent to which an enforcement action can be expected to achieve compliance. ReSTATEMENT (SECOND) OF Foreign Relations Law of the United States $\$ 40$ (a) (1965).

Several courts have adopted this approach. See, e.g., In re Westinghouse Elec. Corp. Uranium Contracts Litig., 563 F.2d 992, 997 (10th Cir. 1977) (related action in Tenth Circuit in which the court reversed a contempt order for refusing to produce documents located in Canada relevant to uranium production in Canada because compliance would be a violation of Canadian law); see also United States v. First Nat'l City Bank, 396 F.2d 897, 901 (2d Cir. 1968) (affirming judgment of civil contempt against a bank for failure to produce documents located in Germany pursuant to a subpoena duces tecum in an antitrust case because American interests in enforcing its competition laws were of greater weight than German national interests in bank secrecy).

69. In re Uranium Antitrust Litig., 480 F. Supp. 1138, 1148 (1979). 
legislation by prohibiting access to those same documents. It is simply impossible to judicially "balance" these totally contradictory and mutually negating actions. ${ }^{70}$

Hearings on discovery sanctions began in March 1980. Settlement negotiations began later that year, and Judge Marshall never ruled on the sanctions. ${ }^{71}$ Judge Marshall's refusal to take account of the blocking statutes and the impending possibility of discovery sanctions may have been an impetus for settlement.

The court's unwillingness to take account of blocking legislation in the Uranium litigation clearly increased tensions between the United States and foreign nations. For example, as discussed in part II of this note, the possibility of the entry of default judgments against Australian producers encouraged passage of the Foreign Antitrust Judgments Act in Australia. ${ }^{72}$ Thus, the court's attitude toward the blocking statute had ramifications that extended far beyond the suit itself.

2. The Laker Airways Litigation. Blocking legislation initiated in the United Kingdom ${ }^{73}$ had a similar effect on the decision of the Court of Appeals for the District of Columbia in Laker Airways v. Sabena, Belgian World Airlines. ${ }^{74}$ In that case, the liquidators of Laker Airways, Ltd. (Laker), a British airline, filed an antitrust action against several major North Atlantic competitors in federal district court. ${ }^{75}$ Laker alleged that two British airlines, British Airways and British Caledonian Airways, and six non-British competitors had conspired to force Laker out of business through predatory pricing agreements.

Laker brought the antitrust suit in the United States because there are no similar antitrust laws in the United Kingdom. The United States had jurisdiction over the case because the conduct at issue had substantial effects within the United States. ${ }^{76}$

Four of the defendants, British Airways, British Caledonian Airways, and two other European airlines, attempted to escape U.S. jurisdiction by seeking from the British courts an interim injunction restraining Laker from pursuing its antitrust action in the United States. ${ }^{77}$ The British High Court of Justice initially granted a preliminary injunction against Laker, preventing Laker from taking "any further steps" to prosecute its U.S. claim against the British

70. Id.

71. The case was settled in March 1981.

72. See supra text accompanying notes 23-24.

73. British Protection of Trading Interests Act, 1980, ch. 11.

74. 731 F.2d 909 (D.C. Cir. 1984).

75. Laker named as defendants four American corporations (Pan American World Airways, Trans World Airlines, McDonnell Douglas Corp., and McDonnell Douglas Finance Corp.) as well as four foreign airlines (British Airways, British Caledonian Airways, Lufthansa, and Swissair). Laker later commenced a second antitrust action, naming as defendants, KLM, Royal Dutch Airlines, and Sabena, Belgian World Airlines. Id. at 917-18.

76. The court noted that Laker's principal creditors were American, and that a great percentage of passengers on North Atlantic air routes are American, so that a predatory pricing scheme would result in increased fares for U.S. passengers. It also ruled that the United States has a substantial interest in regulating the conduct of business within the United States. Id. at 924 .

77. British Airways Bd. v. Laker Airways, [1983] 3 All E.R. 375, 380 (C.A.). 
airlines. ${ }^{78}$ This ruling in turn prompted the district court to issue preliminary injunctions restraining the remaining defendants from taking any actions that would interfere with the progress of the pending case. ${ }^{79}$ The Queen's Bench later refused to grant the British airlines a permanent injunction, ${ }^{80}$ holding that the district court properly had jurisdiction over the matter and that there was no ground for English judicial interference. The court reasoned that the irreparable harm an injunction would cause Laker outweighed any competing interests. ${ }^{81}$ The airlines appealed this decision.

Meanwhile, the British government issued an order under the Protection of Trading Interests Act prohibiting the British airlines from producing any documents located in the United Kingdom for use in Laker's action. ${ }^{82}$ After reconsidering the motion for an injunction in light of the effect of the blocking order, the British Court of Appeal permanently enjoined Laker from proceeding with its antitrust claims against the British defendants. ${ }^{83}$ The court reasoned that because the Protection of Trading Interests Act order prohibited the airlines from relying on their own commercial documents to defend themselves against Laker's charges, pursuit of the action could only result in a "total denial of justice" to the British airlines. ${ }^{84}$

In 1984, the District of Columbia Circuit affirmed the district court's grant of a preliminary injunction restraining KLM and Sabena from seeking British antisuit injunctions. ${ }^{85}$ In reaching its decision, the court was not intimidated by the existence of the British blocking order. It especially took exception to the fact that the order purported to block Laker's use of information located in the United Kingdom against any defendant, British or American. ${ }^{86}$ The court stated:

There is simply no visible reason why the British Executive, followed by the British courts, should bar Laker's assertion of a legitimate cause of action in the American courts, except that the British government is intent upon frustrating the antitrust policies of the American government. The effort of the British therefore is not to see that justice is done anywhere, either in the United States or British courts, but to frustrate the enforcement of American law in American courts against companies doing business in America. ${ }^{87}$

The court also refused to adopt the Timberlane 88 and Mannington

78. Id.

79. Laker Airways v. Pan American World Airways, 559 F. Supp. 1124 (D.D.C. 1983).

80. British Airways Bd. v. Laker Airways, [1984] 1 Q.B. 142.

81. Id. at 165-66.

82. The Protection of Trading Interests (U.S. Antitrust Measures) Order 1983, S.I. 1983, No. 900. The text of this order is reprinted in British Airways Bd. v. Laker Airways, [1983] 3 All E.R. 375, 404-07 (C.A.).

83. British Airways Bd. v. Laker Airways, [1983] 3 All E.R. 375, 395 (C.A.).

84. Id. at 410.

85. Laker Airways v. Sabena, Belgian World Airlines, 731 F.2d 909 (D.C. Cir. 1984).

86. Id. at 940 .

87. Id.

88. Timberlane Lumber Co. v. Bank of America, 549 F.2d 597 (9th Cir. 1976). See supra notes 58,60 . 
Mills ${ }^{89}$ jurisdictional rule of reason analysis to refrain from exercising jurisdiction. It held that it was incompetent to weigh the purely political factors involved in the balancing test espoused by those circuits. ${ }^{90}$ The court also doubted that such a balancing test would promote international comity, noting that in no instance had a court declined to exercise jurisdiction under the interest balancing analysis where the U.S. interests at stake were more than de minimis. It stated: "[C]ourts inherently find it difficult neutrally to balance competing foreign interests. When there is any doubt, national interests will tend to be favored over foreign interests."91

Finally, the Laker court noted it was improper for federal courts, which are not "organs ... of political compromise" 92 to defuse a conflict with foreign law by "jettisoning . . . our [the United States'] jurisdiction."93 The court concluded: "[B]oth institutional limitations on the judicial process and Constitutional restrictions on the exercise of judicial power make it unacceptable for the Judiciary to seize the political initiative and determine that legitimate application of American laws must evaporate when challenged by a foreign jurisdiction." 94

Thus, like the Seventh Circuit in the Uranium litigation, the Laker court did not weigh the existence of a blocking order in its determination to exercise jurisdiction. The D.C. Circuit's opinion in the Laker case created further tension between the United States and Great Britain. The British House of Lords later defused the conflict by reversing the judgment of the Court of Appeal. ${ }^{95}$ However, the blocking order continued to affect the litigation. Similar to the pattern of events in the Uranium litigation, settlement negotiations in the Laker case began shortly after Laker made a broad motion to compel discovery. ${ }^{96}$

89. Mannington Mills, Inc. v. Congoleum Corp., 595 F.2d 1287 (3d Cir. 1979). See supra notes 59,60 .

90. Laker Airways, 731 F.2d at 949.

91. Id. at 951 and n.156 ("effects were so 'speculative and insubstantial' that 'neither the Constitution nor the Sherman Act was intended' to reach the challenged conduct" (citing Montreal Trading Ltd. v. Amax, Inc., 661 F.2d 864, 870 (10th Cir. 1981), cert. denied, 455 U.S. 1001 (1982))).

92. Laker Airways, 731 F.2d at 953.

93. Id.

94. Id. at 954 .

95. British Airways Bd. v. Laker Airways, [1984] 3 W.L.R. 413 (H.L.).

96. Laker moved to compel discovery against defendants British Airways and British Caledonian Airways on March 27, 1985. Plaintiff's Motion to Compel Discovery, Laker Airways v. Sabena, Belgian World Airlines, 731 F.2d 909 (D.C. Cir. 1984). Soon thereafter, the parties settled the case. Laker Airways, No. 82-3362 (D.D.C. Oct. 1, 1985) (stipulation of dismissal).

An earlier decision by Judge Greene hinted that he would not be amenable to an argument that foreign blocking orders provide a valid defense to nonproduction. Laker had filed a motion to compel Lufthansa Airlines to produce documents. Lufthansa claimed that it was precluded under its operating license from producing documents without the approval of the German government. Judge Greene deferred Laker's motion to compel for thirty days in order to give the parties time to reach their own agreement. However, in his opinion, Judge Greene admonished Lufthansa for making bad faith efforts to obtain a waiver from the government so that it could produce the documents. Laker Airways, No. 82-3363 (D.D.C. June 26, 1984) (order deferring entry of ruling on plaintiff's motion to compel discovery for an additional 30 days). He also stated that it is not ipso facto a defense to a discovery request that foreign law prohibits production, and noted that this defense is not necessarily valid even at the sanction stage. Laker Airways, order at 4 (citing United States v. Bank 


\section{B. The Practical Impact of Blocking Legislation on Litigation Strategy}

For litigators in private practice, the blocking statutes present many problems not apparent in the case law itself. These effects surfaced in interviews conducted with private litigators having expertise in both international and antitrust law. This section summarizes the results of these interviews.

Perhaps most obvious, blocking statutes make it more difficult for both parties to get documents needed for litigation. ${ }^{97}$ As one commentator noted, the presence of a blocking statute in litigation leads to a lot of "preliminary skirmishes" over information. ${ }^{98}$ If a foreign defendant is able to anticipate litigation, the presence of a blocking statute in the defendant's country may lead him to keep documents out of the United States. ${ }^{99}$ It will also encourage a defendant to bring the case to its government's attention and to seek a helpful intervention by that government as soon as possible, thereby putting political pressure on the United States Government to take a position as to the suit in the United States. ${ }^{100}$

More often than not, however, the defendant wishes to produce the necessary documents. An ironic and presumably unintended effect of the blocking statutes is that they often prevent the defendant from producing documents favorable to his position. ${ }^{101}$ Foreign governments are not likely to be amenable to their nationals' arguments that favorable material should be released. This reluctance exists because the sovereign concerns underlying the blocking statutes are unaffected by the particulars of actual litigation. ${ }^{102}$

Blocking statutes have other adverse consequences for foreign defendants. For example, the defendant is less likely to raise a successful sovereign compulsion defense to a motion to compel discovery or impose sanctions if the defendant is operating under a blocking statute that is discretionary in nature. ${ }^{103}$ The existence of a blocking order under these conditions exposes the defendant to an argument that he has procured the blocking order for his own advantage. ${ }^{104}$

The existence of a blocking statute also raises problems for plaintiffs. While none of the attorneys interviewed felt that a blocking statute would

of Nova Scotia, 691 F.2d 1384 (11 th Cir. 1982), which enforced a subpoena that required production of documents located in the Bahamas, notwithstanding that compliance would allegedly require violations of a Bahamian bank secrecy law).

97. E.g., Telephone interview with Sanford Litvack, Partner, Dewey, Ballentine, Bushby, Palmer \& Wood (Feb. 11, 1986).

98. Id.

99. Id. Realistically, however, the defendant is not likely to anticipate the suit. Moreover, some blocking legislation prohibits production of its national's documents even if those documents are located in the country where the suit is being brought. See, e.g. Lramium Info. Sec. Regs., Can. Cons. REGS., ch. 366 (1978), issued pursuant to the Atomic Energy Control Act, ch. A-19 (1970).

100. Telephone interview with Joseph Griffin, Partner, Morgan, Lewis \& Bockius (Feb. 12, 1986).

101. Telephone interview with Joel Davidow, Partner, Mudge, Rose, Guthrie, Alexander \& Ferdon (Jan. 12, 1986).

102. See, for example, the explanation behind the Canadian uranium regulations, supra note 16.

103. Joseph Griffin interview, supra note 97.

104. Id. 
discourage plaintiffs from bringing suit, one felt that it might discourage plaintiffs from pursuing certain kinds of remedies. ${ }^{105}$ For example, a blocking statute might discourage a plaintiff from seeking a preliminary injunction. This disincentive exists because successful preliminary injunction motions depend on quick discovery. Faced with a blocking statute which will slow discovery, if not halt it altogether, a judge may be unwilling to grant such a remedy. ${ }^{106}$ Moreover, a foreign plaintiff wishing to sue in the United States must make certain that its government is not going to impose a blocking order halting production of plaintiff's documents. If the plaintiff fails to do so, he risks a nonsuit or imposition of sanctions for noncompliance with his country's blocking statute. ${ }^{107}$

Because of the effect of a blocking statute on litigation, the best strategy for a U.S. plaintiff suing a foreign defendant is to raise the issue of the blocking statute early in the litigation. The reasons are twofold. First, the existence of a blocking statute is a pressure point for defendants. While the tactic may seem to frustrate the defendant, if in fact a judge feels that a defendant is "hiding behind" the blocking statute, he may lean toward the plaintiff early in the litigation. Second, raising the existence of a blocking statute highlights the possibility of sanctions early. ${ }^{108}$

Ironically, while the blocking statutes impact both sides of the litigation, they seem to present more problems for foreign defendants than for domestic plaintiffs. Indeed, the blocking statutes may be a major impetus for settlement. ${ }^{109}$ This observation is consistent with the results in the Uranium and Laker Airways cases. ${ }^{110}$ Once a judge serves notice that he is about to impose discovery sanctions, and a defendant is unsuccessful at obtaining a waiver from his government enabling him to produce the information, a defendant is likely to settle. Settlement is attractive because the defendant is in a no-win situation; he will either be subject to discovery sanctions here or sanctions for violating his own blocking law. ${ }^{111}$

The existence of a blocking statute also makes litigation more expensive. Moreover, most of the attorneys agreed that the blocking statutes seem to be an effective way of getting the attention of each party's governments. In sum, the blocking statutes are an effective means of "raising the stakes of the game."'112

Because blocking statutes have had adverse effects on antitrust litigation in the United States, the United States has an interest in seeing these blocking statutes repealed. Blocking statutes create tensions between the United States

105. Telephone interview with James Atwood, Partner, Covington \& Burling (Feb. 18, 1986).

106. Id.

107. Telephone interview with Douglas Rosenthal, Partner, Sutherland, Asbill \& Brennan (Feb. 12,1986 ).

108. Sanford Litvack interview, supra note 97.

109. Joseph Griffin interview, supra note 100 .

110. See supra text accompanying notes 71,96 .

111. Joseph Griffin interview, supra note 100.

112. Id. 
and the other country whose resident corporation is a defendant in an antitrust suit brought in the United States. This result is particularly likely in cases in which the court refuses to factor the existence of a blocking statute into its decisions. ${ }^{113}$ Moreover, the foreign hostility created by U.S. antitrust decisions can have spillover effects in areas having nothing to do with antitrust law. Finally, while the executive branch can decrease the likelihood that a country will implement its blocking legislation through its exercise of prosecutorial discretion, it cannot control a private litigant's decision to sue.

Foreign nations with blocking legislation also have an incentive to resolve the extraterritoriality problem. Their own corporations are often adversely affected by invocation of blocking legislation that is designed to protect them. The British, for example, have indicated that a "legislative SALT" talk that would lead to congressional restraints on international antitrust enforcement might end the "legislative arms race." 114 It remains to be seen whether an acceptable congressional solution will precipitate disarmament.

\section{IV}

\section{Proposed Legislative Solutions to the Extraterritoriality Problem}

Recently, Senator Dennis DiConcini introduced a bill that addresses the problem of the extraterritorial application of U.S. antitrust laws. The bill, Senate Bill 572,115 attempts to resolve the conflict among the circuits regarding the proper jurisdictional test in international antitrust cases. More importantly, the bill represents an attempt by the United States to lessen the international conflict arising from extraterritorial enforcement of U.S. competition laws.

Section 102 of the bill requires a court considering a motion to dismiss for lack of subject matter jurisdiction to rule on the motion prior to any determination on the merits. ${ }^{16}$ Under this section, a judge would conduct only discovery or other proceedings related to the motion to dismiss before considering the substantive issues of the case. ${ }^{117}$ This provision is designed to address complaints by other countries that the United States has

113. Rosenthal interview, supra note 107

114. During the Parliamentary Debates on the British Protection of Trading Interests Act, British Undersecretary for Trade Tebbit responded as follows to a question of another British official who feared that the United States might pass legislation authorizing anticlawback injunctions in antitrust cases:

He asked whether there would be tit-for-tat actions-or hostile ping-pong diplomacy

We very much hope not. We trust that the United States authorities will see the dangers of that and avoid entering a legislative arms race with us. Perhaps they might be prepared to discuss a legislative SALT agreement at some time and get out of this race.

972 Parl. DeB. H.C. (5th ser.) 1590 (1979) (emphasis added); see also Danaher, .tuti-Antitrust Laur: The Clawback and Other Features of the United Kingdom Protection of Trading Interests Act, 1980, 12 LAw \& PoL'Y IN INT'L Bus., 947, $971 \&$ n.147 (1980).

115. S. 572, 100th Cong., lst Sess. (1987). Another article in this issue discusses pending legislative solutions to the extraterritoriality conflict. See Small, supra note 8, at 300.

116. S. 572, 100th Cong., 1st Sess. § 102 (1987).

117. Id. 
"unparalleled provisions for wide-ranging pretrial discovery."118 Such provisions, complaining nations argue, permit parties to conduct protracted discovery unrelated to the merits of the jurisdictional claim even though the case may ultimately be dismissed on jurisdictional grounds. ${ }^{119}$

Section 103 codifies the jurisdictional rule of reason applied in the Timberlane and Mannington Mills decisions. ${ }^{120}$ It requires a judgment dismissing an antitrust action whenever the rule of reason requires dismissal. Section 103 also lists six factors that the courts must use in determining whether to dismiss the action:

(1) $[T]$ he relative significance, to the violation alleged, of conduct within the United States as compared to conduct abroad;

(2) the nationality of the persons involved in or affected by the conduct;

(3) the presence or absence of a purpose to affect United States consumers or competitors;

(4) the relative significance and foreseeability of the effects of the conduct on the United States as compared with the effects abroad;

(5) the existence of reasonable expectations that would be furthered or defeated by the action; and

(6) the degree of conflict with foreign law or articulated foreign economic policies. $^{121}$

The bill addresses concerns that the court will be required to weigh political factors in its balancing test in several ways. First, the balancing test excludes some obviously political factors contained in other tests. For example, the bill excludes the Mannington Mills requirement that the court consider the possible effect on foreign relations if jurisdiction is exercised. ${ }^{122}$ Second, the bill also excludes an examination of the effect of the exercise of jurisdiction on international commerce, a factor included in an earlier version of the bill but criticized as requiring a balancing of political factors. Finally, the bill expressly provides that a court should not consider the effect of exercising jurisdiction on the foreign political relations of the United States. ${ }^{123}$

Despite these provisions, the bill does not completely prevent the courts from introducing political factors into their decisions. First, while the sixth factor appears neutral, it does require political assessments. For a court to determine the degree of conflict with foreign economic policies, it must assess what conduct will offend foreign governments. In addition, the six-factor test

118. 131 Cong. Rec. S1162 (daily ed. Feb. 6, 1985).

119. Although the bill addresses this problem, it may not fully resolve this issue. The reason is that facts relating to jurisdiction may be intertwined with those relating to the merits. Therefore, under the DeConcini scheme, protracted discovery may nevercheless occur. See S. 397 Hearings, supra note 4 , at 16 .

120. S. 572, 100th Cong., 1 st Sess. \& 103 (1987). The bill also applies the doctrine of forum non conveniens to antitrust suits. $I d . \S 104$.

121. Id. §103(a).

122. Compare Mannington Mills factor 6, supra note 60.

123. S. 572, 100th Cong., Ist Sess. $\$ 103$ (1987). 
is not exclusive. Therefore, courts are free to weigh other factors into their jurisdictional determinations. ${ }^{124}$

Although the bill envisions that none of the factors will be dispositive of the jurisdictional issue, some of the factors are arguably inappropriate considerations for the court. For example, the economic effects of a course of conduct, rather than the place of that conduct, is the key determinant of an appropriate exercise of jurisdiction, since conduct that produces no consequences within U.S. borders causes no damage in the United States. Therefore, the relative significance of the conduct within the United States compared with the amount of conduct abroad should be irrelevant.

An earlier version of the bill included an additional jurisdictional requirement obligating the court to dismiss any action in which the Attorney General certified to the court that the action would interfere with foreign relations. ${ }^{125}$ This section was criticized, and subsequently deleted, for three reasons. First, empowering the Attorney General to dismiss a case creates a separation of powers conflict between the judicial and executive branches, because the power of dismissal normally rests with the courts. Second, if the Attorney General refuses to exercise his power of dismissal in a particular case, his action will undoubtedly cause tension between the United States and the other government concerned. Finally, granting the Attorney General such broad powers gives "the appearance that the ability of private litigants to pursue their legal remedies in the United States courts is subject to political manipulation."126

Although this particular provision was fraught with difficulties, the current bill provides no mechanism by which foreign policy considerations can weigh into the determination of whether to exercise jurisdiction. ${ }^{127}$ This result may be undesirable because the existence of political problems concerning jurisdiction created the extraterritoriality conflict. Absent any means to ensure that political factors weigh into the determination whether to exercise

124. Section 103 states that courts shall rely "primarily on ... the ... factors" enumerated in that section in making its jurisdictional determinations. An earlier draft of the bill merely stated that courts shall consider "such factors as" those enumerated in the bill. S. 397, 99th Cong., 1st Sess., $\$ 3$ (1985). Although this version contains more restrictive language, it still does not make the balancing test exclusive.

Janusz Ordover points out a further flaw with balancing tests generally. He argues that "[b]alancing is a rather empty prescription for ascertaining jurisdiction ... unless there exists some idea of the appropriate weights to be assigned to conflicting interests. Assigning a very low weight to the genuine interests of the foreign sovereign is a very crude position. In fact, it may provoke retaliation by the country whose interests have been undervalued." Ordover, Conficts of Jurisdiction: Antitrust É Industrial Policy, Law \& Contemp. Probs., Summer 1987, at 165, 177. Senate Bill 572 provides no guidance on the relative weights to be assigned each conflicting interest.

125. S. 397, 99th Cong., 1st Sess. § 3(c) (1985).

126. See Memorandum to Cabinet Councils on Changes in Antitrust Laws, reprinted in 49 Antitrust \& Trade Reg. Rep. (BNA) No. 1242, at 946, 951 (1985). The Working Group on Antitrust Review prepared this memorandum. The group was chaired by representatives of the Justice and Treasury Departments, with participants from the Office of Management and Budget, Office of U.S. Trade Representatives, Council of Economic Advisors, White House, and the State, Commerce, and Labor Departments.

127. The Attorney General does not have the power to dismiss cases, and the court's jurisdictional balancing test excludes political factors. 
jurisdiction, it is doubtful that any country will find this change to be an acceptable solution. As the D.C. Circuit recognized in Laker Airways, judicial inquiry into "neutral" factors leads "to the obvious conclusion that jurisdiction could be exercised or that there is a conflict, but does not suggest the best avenue of conflict resolution." 128 Absent guidance from the executive branch, the courts will therefore tend to favor U.S. interests. The courts will decide disputes based on U.S. law (including substantive antitrust rules and discovery procedures) despite the existence of substantial foreign interests in the case.

The bill also provides for a Commission to make recommendations to the President concerning the extraterritorial application of U.S. laws. The bill requires the Commission to study:

(1) [T]he extent to which unresolved jurisdictional conflicts (including situations where foreign laws are applied extraterritorially) impose serious trade barriers, costs, and uncertainties for United States business;

(2) the principles for setting appropriate limits on the application and enforcement of U.S. law reaching the overseas conduct of foreigners;

(3) ... the types of conflicts between the laws and policies of the United States and other sovereign states that can and should be resolved by diplomacy . . . [or] . . . litigation in United States or foreign courts or by other legal procedures;

(4) the laws or mechanisms that would be appropriate for removing essentially diplomatic disputes from adjudication;

(5) changes in the methods of conducting litigation that might better balance the vindication of valid legal rights with the burdens such litigation imposes in international commerce and foreign relations; and

(6) the mechanisms or standards that exist, or can be established, either under United States domestic law or under bilateral or multilateral legal arrangements, for resolving unavoidable jurisdictional conflicts between the United States and other sovereign states. 129

Establishing a Commission to study the extraterritoriality problem merely postpones resolution of the conflict. The objective of the Commission is to examine legislative solutions to the extraterritoriality problem. Since this problem has been studied extensively by those working on current proposals, it is unlikely that the Commission will find a solution that is much different than those that have already been advanced.

A previous version of the DeConcini bill proposed to eliminate the treble damage remedy in antitrust suits brought against foreign defendants. ${ }^{130}$ This provision was deleted after the Reagan Administration proposed its own, more comprehensive, antitrust reform package. ${ }^{131}$ Part of the package proposes to limit the treble damage remedy in antitrust cases to those injuries sustained by reason of the plaintiff "having been overcharged or underpaid by any person subject to liability under the antitrust laws for such damages

128. I.aker Airways v. Sabena, Belgium World Airlines, 731 F.2d 909, 949 (D.C. Cir. 1984).

129. S. 572, 100th Cong., Ist Sess., $\$ 202(1987)$. The title of the Commission would be the "Javits Commission on the Extraterritorial Application of United States Law." See id. § 202(a).

130. S. 397, 99th Cong., 1st Sess., \& 6 (1985).

131. S. 539, 100th Cong., 1st Sess. (1987). The provisions on antitrust reform are contained in subtitle B of the proposed Trade, Employment, and Production Act of 1987. Because this bill does not assign weights to each factor in the balancing test, Ordover's criticism of interest balancing applies to this bill as well. See supra note 124 . 
"132 The provision applies to all private antitrust suits, including those in which there is a foreign defendant. Its purpose is to limit the treble damage remedy to cases in which the defendant has engaged in conduct unquestionably detrimental to the economy. According to the Administration's view, applying the treble damage remedy to other cases punishes potentially procompetitive practices. ${ }^{133}$

The detrebling scheme in the old DeConcini bill might be criticized for sacrificing domestic antitrust goals in order to appease foreign governments. That concern is less critical now that the Administration's proposal mandates across-the-board detrebling. Because detrebling now applies to domestic and international cases alike, the DeConcini measure on its face does not sacrifice domestic policy goals in order to achieve international comity. Nevertheless, the DeConcini bill may result in such a sacrifice anyway. The reason is that it may make even less sense to eliminate treble damages in international antitrust cases than to do so in domestic cases. Treble damages provide an incentive for plaintiffs to detect antitrust violations. ${ }^{134}$ In international cases, blocking statutes impede the ability of plaintiffs to prove such violations. This difficulty may make it desirable to award plaintiffs in international cases a trebled damage award even if such a remedy is not available in domestic cases.

This argument fails where passage of the detrebling scheme results in simultaneous decisions by other countries to repeal their blocking statutes or at least to refrain from invoking them. If domestic policy makers do not

132. Id. \$ 4113. To provide additional compensation for those plaintiffs eligible to collect only actual damages, the bill provides that such plaintiffs shall receive prejudgment interest on those claims, unless the court determines that such an award would be unjust under the circumstances. Id. $\$ 4112$. Plaintiffs receiving trebled awards, however, would only receive prejudgment interest in cases in which the defendant acted in bad faith. See id. §4113.

The rationale for maintaining treble damages in cases in which there is an overcharge or underpayment is as follows:

Covert concerted practices such as price fixing, bid rigging, divisions of markets, and allocation of customers must be strongly deterred. Suits brought by victims of these practices, often customers or small business customers, are generally based on overcharges or underpayments. Antitrust Remedies Reform: Hearings on S. 2022 and S. 2162 Before the Senate Comm. on the Judiciary, 99th Cong., 2d Sess. 34 (1986) [hereinafter Antitrust Remedies Reform Hearings] (statement of Douglas Ginsburg, Assistant Attorney General, Antitrust Division, Justice Department). Last term, the Reagan Administration's proposals on antitrust reform were contained in S. 2022 and S. 2162

133. At the hearings on S. 2162 (reintroduced as S. 539), Ginsburg testified as follows with respect to the anticompetitive effects of current antitrust laws:

The current punitive damage provisions apply uniformly to all types of practices that may, in particular circumstances, be found to violate the antitrust laws-no matter how close the question. In so doing, they have to actually inhibit some procompetitive activities. . . S. 2162 reflects that fact that it simply makes no legal or economic sense for a punitive remedy designed strongly to deter clearly harmful conduct like price fixing to be applied equally to ordinary, open business activities that, after a full trial on their economic effects, may or may not be found to have been anticompetitive.

Antitrust Remedies Reform Hearings, supra note 132, at 31.

134. By encouraging private litigants to detect antitrust violations, the treble damage remedy furthers the overall social and economic advantages of the antitrust laws. The treble damages sanction also serves to deter repeated violations and discourage potential violators. Finally, the threat of treble damages encourages defendants to settle well-founded claims. See Antitrust Remedies Reform Hearings, supra note 132, at 59 (Statement of Donald Turner, Partner, Wilmer, Cutler \& Pickering, Washington, D.C.). 
receive assurances that international comity will result from passage of the bill, however, the disincentives associated with a detrebling scheme may damage the U.S. policy of punishing anticompetitive conduct that has direct, substantial, and reasonably foreseeable effects in the United States. ${ }^{135}$

In addition to undercutting some policy objectives of U.S. antitrust laws, there is no guarantee that the Administration's detrebling provision will appease foreign governments. Foreign countries want the United States to abolish treble damages in all antitrust cases because they do not enforce similar competition laws. Under the Administration's bill, however, awards still will be trebled in some cases, such as in cases of proven price fixing and bid rigging. ${ }^{136}$ Thus, where a foreign defendant is accused of price fixing or bid rigging, conflict would still remain. For example, in an action related to that brought by Laker Airways, consumers alleged that the conspiracy among Laker's competitors caused them to pay higher prices on trans-Atlantic flights. Even under the Administration's plan, the consumers would have received treble damages had they won after a trial on the merits. ${ }^{137}$

\section{The Probable Effects of the Proposed Legislation on the Blocking Statutes}

It is questionable whether codification of the jurisdictional rule of reason will cause other countries to change their blocking legislation. As discussed above, ${ }^{138}$ courts employing the balancing approach have only refrained from exercising jurisdiction where the U.S. interests at stake were de minimis. Thus, foreign countries may not consider allowing U.S. judges to weigh U.S. interests to be much of a concession.

Coupling this balancing approach with detrebling provisions may improve foreign relations. Without allowing for any executive branch participation, however, there is no means by which foreign policy concerns can weigh into jurisdictional disputes. Even with provisions for executive branch participation, it is unlikely that these efforts will cause other countries to consider repealing their blocking legislation. Although the discovery blocking statutes discussed in this note were enacted in response to the extraterritorial application of U.S. antitrust laws, blocking statutes also represent a general distaste for U.S. discovery procedures. ${ }^{139}$ Moreover, although aimed

135. See Foreign Trade Antitrust Improvements Act of 1982, 15 U.S.C. $\S 6 a(1982)$.

136. See supra note 132 .

137. In re Atlantic Air Travel Antitrust Litig., No. 84-1013 (D.D.C. fled Mar. 30, 1980). This case was later settled. See In re Atlantic Air Travel Antitrust Litig., No. 84-1013, Memorandum Order (D.D.C. Mar. 18, 1986).

138. See supra note 91 and accompanying text.

139. Unlike the United States, many foreign countries limit pretrial disclosure of documents to "specifically identified documents in possession of a party"; in addition, many countries "do not permit pre-trial depositions (except to preserve testimony of persons likely to be unavailable for trial)." Restatement (Revised) of Foreign Relations LaW of the United States $\$ 420$ reporters' note (1982) (Tent. Draft No. 3 1982) (international conflict concerning discovery abroad). 
primarily at U.S. antitrust laws, the language of the blocking statutes applies to all actions. Countries with blocking legislation have applied their statutes successfully to other types of disputes. For example, the Protection of Trading Interests Act has been invoked in cases not involving antitrust violations. ${ }^{140}$ In addition, the French blocking statute has prevented the Securities and Exchange Commission from obtaining third party evidence in several securities investigations. ${ }^{141}$ Perhaps most important, blocking statutes also represent an assertion of sovereignty. Therefore, their symbolic value remains even after their practical impact has died. Finally, laws often remain on the books simply as a result of legislative inertia.

On the other hand, adopting a legislative solution may at least decrease the use of blocking statutes. In addition, countries like France with automatic blocking provisions may modify their statutes to make them discretionary. Moreover, U.S. legislative initiatives may encourage other types of solutions, including additional antitrust cooperation agreements.

\section{VI}

\section{Conclusion}

The private treble damages remedy in antitrust cases in the United States has clearly caused conflicts with our trading partners. Invocation of blocking statutes in antitrust cases has encouraged the United States to reevaluate the application of its antitrust policies toward conduct abroad. The adverse impact that blocking legislation has had on nationals of the country implementing the statutes gives these countries an incentive to resolve the extraterritoriality problem. If passed, the legislative initiative may improve foreign relations and decrease use of the blocking statutes, but it is doubtful that they will inspire other countries to repeal their blocking laws. Moreover, legislative initiatives that mandate deference to foreign governments on jurisdictional matters and that limit recovery in most antitrust cases to actual damages will discourage private U.S. plaintiffs with meritorious claims from

140. In Alan J. Ridge \& Co., Comm. Fut. L. Rep. (CCH) I 21,819 (Mar. 22, 1983), the U.S. Commodities Futures Trading Commission ordered Ridge, a coffee trader, to open its records for inspection so that the Commission could determine whether Ridge was manipulating futures trading on the New York Coffee, Sugar and Cocoa Exchange. The British Secretary for Trade issued an order under the Protection of Trading Interests Act instructing the British defendant not to comply with the Commission's request for documents. The Commission therefore held that Ridge violated reporting provisions of the Commodity Exchange Act and prohibited him from trading in any United States market for one year.

The Protection of Trading Interests Act was invoked again when in 1982 the United States prohibited any U.S. subsidiaries operating overseas from trading equipment with the Soviet Union that could be used in construction of the Soviet pipeline. The British issued an order instructing the companies affected by the U.S. embargo to perform its contracts although performance would violate the embargo. Protection of Trading Interests (U.S. Reexport Control) Order 1982, S.I. 1982, No. 885, reprinted in 21 INT'L Legal Materials 851, 852 (1982). The United States did not, however, impose any sanctions on the subsidiaries for noncompliance with the U.S. embargo. See Note, The Impact of the British Protection of Trading Interests Act of the United States Antitrust Suit Brought By Laker Airways Against British Airways and British Caledonian, 14 GA. J. INT'L \& CoMP. L. 181, $191-200$ (1984).

141. Telephone interview with Michael Mann, Director, Office of International Assistance, Securities and Exchange Commission (Feb. 10, 1986). 
suing foreign defendants. Given the important policies underlying U.S. antitrust laws, ${ }^{142}$ the modest impact the changes are likely to have on foreign policies may not be worth the potential costs associated with the current proposals. Domestic concerns should therefore dominate any change in U.S. antitrust policy aimed at resolving the extraterritoriality conflict. ${ }^{143}$

\section{PostSCRIPT}

At the time this article went to print, S.539 and S.572 were both in committee.

142. The Supreme Court once called U.S. antitrust laws the "Magna Carta of free enterprise," stating that: "they are as important to the preservation of economic freedom and our free-enterprise system as the Bill of Rights is to the protection of our fundamental personal freedoms." United States v. Topco Assocs., 405 U.S. 596, 610 (1972).

143. Ordover suggests an alternative solution to the extraterritoriality conflict. See Ordover, supra note 124, at 173-77. James Atwood suggests a resolution to jurisdictional conflict over export cartels. See Atwood, Conficts of Jurisprudence in the Antitrust Field: The Example of Export Cartels, LAw \& Contemp. Probs., Summer 1987, at 153. Professor Wood criticizes both of these approaches and offers her own solution. See Wood, Conflicts of Jurisdiction in Antitrust Law: A Comment on Ordover and Atwood, Law \& Contemp. Probs., Summer 1987, at 179. 